\title{
Knowledge, attitudes, and practices among health care providers regarding complementary and alternative medicine in Trinidad and Tobago
}

\author{
Mandreker Bahall ${ }^{1,3^{*}}$ and George Legall ${ }^{2}$
}

\begin{abstract}
Background: Health care providers are often ill prepared to interact about or make acceptable conclusions on complementary and alternative medicine (CAM) despite its widespread use. We explored the knowledge, attitudes, and practices of health care providers regarding CAM.

Methods: This cross-sectional study was conducted between March 1 and July 31, 2015 among health care providers working mainly in the public sector in Trinidad and Tobago. A 34-item questionnaire was distributed and used for data collection. Questionnaire data were analysed using inferential and binary logistic regression models.

Results: Response rate was 60.3\% (362/600). Responders were 172 nurses, 77 doctors, 30 pharmacists, and 83 other health care providers of unnamed categories (mainly nursing assistants). Responders were predominantly female (69.1\%), Indo-Trinidadian (55.8\%), Christian (47.5\%), self-claimed "very religious" (48.3\%), and had <5 years of working experience (40.6\%). The prevalence of CAM use was $92.4 \%$ for nurses, $64.9 \%$ for doctors, $83.3 \%$ for pharmacists, and $77.1 \%$ for other health care providers. The majority (50-75\%) reported fair knowledge of herbal, spiritual, alternative, and physical types of CAM, but had no knowledge of energy therapy and therapeutic methods. Sex, ethnicity, and type of health care provider were associated with both personal use and recommendation for the use of CAM. Predictors of CAM use were sex, religion, and type of health care provider; predictors of recommendation for the use of CAM were sex and type of health care provider. About half of health care providers (51.4\%) and doctors (52\%) were likely to ask their patients about CAM and $<15 \%$ were likely to refer patients to a CAM practitioner. However, health care providers expressed interest in being educated on the subject. Doctors (51.9\%) and pharmacists (63.3\%) said that combination therapy is superior to conventional medicine alone. Less than 10\% said conventional medicine should be used alone.

Conclusion: Knowledge about CAM is low among health care providers. The majority engages in using CAM but is reluctant to recommend it. Predictors of CAM use were sex, religion, and profession; predictors of recommendation for the use of CAM were sex and profession. Health care providers feel the future lies in integrative medicine.
\end{abstract}

Keywords: Complementary and alternative medicine, Expectations, Health care provider, Predictors, Satisfaction

\footnotetext{
* Correspondence: vmandrakes@hotmail.com

${ }^{1}$ School of Medicine and Arthur Lok Jack Graduate School of Business,

University of the West Indies, St. Augustine, Trinidad and Tobago

${ }^{3}$ House \#57 LP 62, Calcutta Road Number 3, McBean, Couva, Trinidad,

Trinidad and Tobago

Full list of author information is available at the end of the article
} 


\section{Background}

Advances in conventional health care have led to improved morbidity, mortality, and quality of life. However, complementary and alternative medicine (CAM) is still widely used across the globe. CAM is defined as "a group of diverse medical and health care systems, practices, and products that are not generally considered part of conventional medicine" [1]. The global prevalence of CAM use is $9.8-76.0 \%$ [2] and varies greatly from country to country, e.g., $38 \%$ in the United States among adults [3], 51.8\% in the United Kingdom [4], 68.9\% in Australia [5], and 74.8\% in South Korea [6]. In Trinidad and Tobago, inhabitants have been traditionally exposed to home remedies and unconventional medical practices [7] that are still used in part due to the lack of available conventional health care [8] but also to improve holistic care $[9,10]$. The types of CAM used in Trinidad and Tobago include herbal medicines [11-13], massage [14], Traditional medicine [15], megavitamins, folk remedies, energy healing, and homeopathy [16], which are similar to those used commonly in the United States [17]. Other types of CAM used in Trinidad and Tobago are special prayers [18], a multitude of vitamins for healing and vitality ("boosters"), chelation therapy, Reiki therapy [19], Chinese and Ayurvedic medicine [18] and acupuncture [20].

CAM is of medical interest because of its perceived benefits [10]. According to patients, CAM is used for curing [21], counteracting the side effects of conventional medicine [22, 23], providing and promoting wellness and holistic care [24], maintaining wellness [25], and fulfilling the expectations of health care providers [26]. Many patients present to health care providers to treat complications of CAM [27], including drug interactions [28], and for advice. This is compounded by pharmacists' and physicians' lack of knowledge, confidence, and training to provide proper guidance to the increasing number of CAM users [29]. HCPs have also developed a heightened interest about CAM [30]. Furthermore, the issues of safety and efficacy, lack of supporting scientific evidence, and non-disclosure of information [31] have made CAM a major public health problem leading to delayed treatment, disease complications, and even death [32]. This study explores the knowledge, attitudes, and practices of HCPs with regard to CAM.

\section{Methods}

This cross-sectional study was conducted between March 1, 2015 and July 31, 2015 among all doctors, nurses, pharmacists and other clinical staff of any ethnicity and gender working mainly in the public health sector of one of the five Regional Health Authorities in Trinidad and Tobago and general practitioners working in Trinidad. The inclusion criterion was consent to participate in the study. The data collection instrument was a 34-item self-administered questionnaire that included items related to demographics, personal and recommended use of various CAM therapies; knowledge, referral and recommendation, reasons and influences for prescribing CAM; attitudes and practices towards CAM usage in the present and future. The key demographic variables were sex, marital status, ethnicity, educational level, employment status, religion, religiosity, and type of HCP. The sample size of 600 was determined by methods described by Lwanga et al. and represents the minimum sample size required to estimate the percentage of target population who uses CAM with a $4 \%$ margin of error [33].

Descriptive and inferential statistical analysis was performed using SPSS version 20 [34] (Chicago, IL, USA). Descriptive methods included frequency tables and graphs for data presentation. Inferential methods included regression analysis and tests of hypothesis including tests of association. Binary logistic regression was used to identify predictors of personal use and recommendation for the use of CAM. All hypotheses were tested at the $5 \%$ level of significance.

\section{Results}

A total of 600 questionnaires were distributed, and 362 were returned. The overall response rate was $60.3 \%$ (Table 1). Responders were predominantly female $(n=$ $250 ; 69.1 \%)$, Indo-Trinidadian $(n=202 ; 55.8 \%)$, Christian religious affiliation $(n=172,47.5 \%)$, self-claimed "very religious $(n=175,48.3 \%)$ and had been in practice for less than five years $(n=148 ; 40.6 \%)$.

The prevalence of CAM use was $92.4 \%(158 / 172)$ for nurses, 64.9\% (50/77) for doctors, 83.3\% (25/30) for pharmacists, and $77.1 \%(64 / 83)$ for other HCPs (Fig. 1). The majority (50-75\%) reported fair knowledge of herbal, spiritual, alternative, and physical types of CAM, but no knowledge of energy therapy and therapeutic methods (Table 2). Sex, ethnicity, and profession (type of $\mathrm{HCP}$ ) were associated with both personal use and recommendation for the use of CAM, while religion, religiosity, and years of practice were not associated (Table 3 ). Binary logistic regression analysis identified sex, religion, and type of HCP as predictors of CAM use (Table 4), and sex and type of HCP as predictors of recommendation for the use of CAM (Table 5). There was no significant correlation between the reported level of knowledge of CAM and the HCP category, with the exception of pharmacists (Table 6).

In general, HCPs remained neutral or were unlikely or very unlikely to recommend CAM. Doctors, more than other HCPs, were most likely to ask their patients about CAM usage (67.5\%) and recommend CAM the 
Table 1 Frequency distribution of selected demographics per type of health care provider $^{\mathrm{a}}$

\begin{tabular}{|c|c|c|c|c|c|}
\hline \multirow[t]{2}{*}{ Variable } & \multicolumn{5}{|c|}{ Type of health care provider } \\
\hline & $\begin{array}{l}\text { Doctor } \\
n(\%)\end{array}$ & Nurse & Pharmacist & Other & Total \\
\hline Response rate & $77(21.3)$ & $172(47.5)$ & $30(8.3)$ & $83(22.9)$ & $362(60.3)$ \\
\hline \multicolumn{6}{|l|}{ Gender } \\
\hline Male & $45(58.4)$ & $10(5.8)$ & $12(40.0)$ & $45(54.2)$ & $112(30.9)$ \\
\hline Female & $32(41.6)$ & $162(94.2)$ & $18(60.0)$ & $38(45.8)$ & $250(69.1)$ \\
\hline \multicolumn{6}{|l|}{ Years of practice } \\
\hline$<5$ & $43(55.8)$ & $49(25.8)$ & $20(66.7)$ & $35(42.7)$ & $148(40.6)$ \\
\hline $5-10$ & $8(10.4)$ & $46(26.7)$ & $3(10.0)$ & $10(12.2)$ & $67(18.5)$ \\
\hline $11-20$ & $4(5.2)$ & $20(11.6)$ & $4(13.3)$ & $9(11.0)$ & $37(10.2)$ \\
\hline $21-30$ & $7(9.1)$ & $16(9.3)$ & $2(6.7)$ & $8(9.8)$ & $33(9.1)$ \\
\hline $31-40$ & $13(16.9)$ & $28(16.3)$ & $0(0.0)$ & $13(15.9)$ & $54(14.9)$ \\
\hline$>40$ & $2(2.6)$ & $13(7.6)$ & $1(3.3)$ & $7(8.5)$ & $23(6.4)$ \\
\hline \multicolumn{6}{|l|}{ Ethnicity } \\
\hline Afro-Trinbagonian & $11(14.3)$ & $63(36.8)$ & $1(3.3)$ & $8(9.6)$ & $83(22.9)$ \\
\hline Indo-Trinbagonian & $50(64.9)$ & $72(42.1)$ & $28(80.0)$ & $56(67.5)$ & $202(55.8)$ \\
\hline Mixed & $11(14.3)$ & $33(19.3)$ & $4(13.3)$ & $14(16.9)$ & $62(17.1)$ \\
\hline Other & $5(6.5)$ & $3(1.8)$ & $1(3.3)$ & $5(6.0)$ & $15(4.2)$ \\
\hline \multicolumn{6}{|l|}{ Religious affiliation } \\
\hline None & $1(1.6)$ & $10(7.2)$ & $0(0.0)$ & $3(4.4)$ & $14(3.9)$ \\
\hline Islamism & $9(14.8)$ & $8(5.8)$ & $6(21.6)$ & $5(7.4)$ & $28(7.8)$ \\
\hline Hinduism & $22(36.1)$ & $21(21.0)$ & $7(30.4)$ & $18(26.5)$ & $76(21.0)$ \\
\hline Christianity & $29(47.5)$ & $91(65.9)$ & $10(43.5)$ & $42(61.8)$ & $172(47.5)$ \\
\hline \multicolumn{6}{|l|}{ Religiosity } \\
\hline Not religious & $12(16.7)$ & $20(11.8)$ & $1(3.3)$ & $9(10.8)$ & 42 (11.6) \\
\hline Not very religious & $22(30.6)$ & $59(34.9)$ & $14(46.7)$ & $31(37.3)$ & $126(34.8)$ \\
\hline Very religious & $33(45.8)$ & $87(51.5)$ & $15(50.0)$ & $40(48.2)$ & $175(48.3)$ \\
\hline Extremely religious & $5(6.9)$ & $3(1.8)$ & $0(0.0)$ & $3(3.6)$ & $11(3.0)$ \\
\hline
\end{tabular}

${ }^{\mathrm{a}}$ Excludes non-responses

Data are the number (percentage)

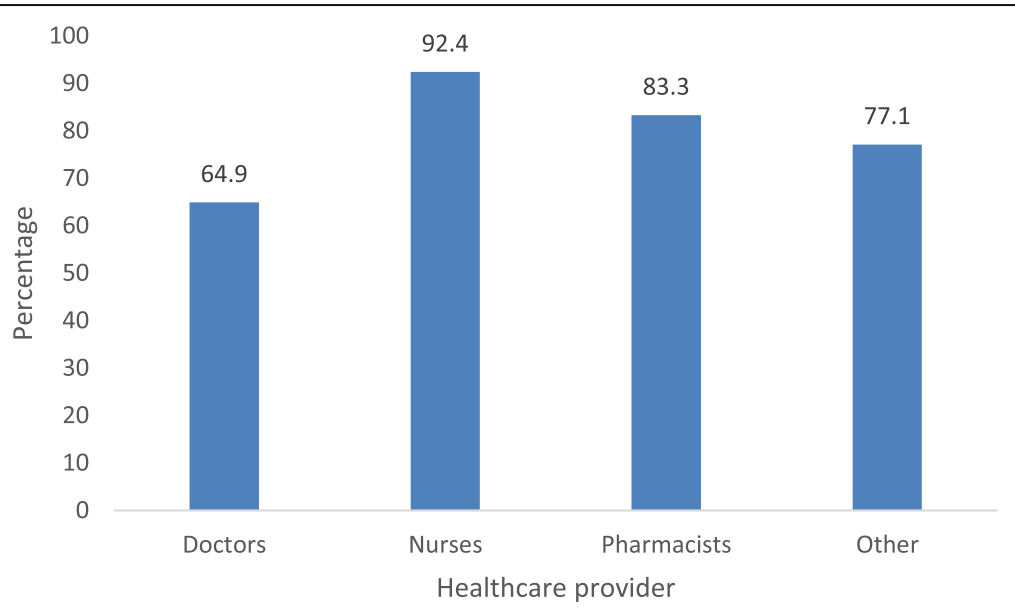

Fig. 1 CAM usage per type of health care provider 
Table 2 Reported level of knowledge of locally used CAM methods per type of health care provider

\begin{tabular}{|c|c|c|c|c|c|c|c|}
\hline \multirow[b]{2}{*}{ Health care provider } & \multirow[b]{2}{*}{ Knowledge level } & \multirow[b]{2}{*}{$\begin{array}{l}\text { Herbal } \\
n(\%)\end{array}$} & \multicolumn{5}{|l|}{ CAM method } \\
\hline & & & $\begin{array}{l}\text { Spiritual } \\
n(\%)\end{array}$ & $\begin{array}{l}\text { Alternative } \\
n(\%)\end{array}$ & $\begin{array}{l}\text { Physical } \\
n(\%)\end{array}$ & $\begin{array}{l}\text { Energy } \\
n(\%)\end{array}$ & $\begin{array}{l}\text { Therapeutic } \\
n(\%)\end{array}$ \\
\hline \multirow[t]{3}{*}{ Doctors $(n=77)$} & None & $4(5.2)$ & $18(23.4)$ & $34(44.2)$ & $14(18.2)$ & $53(68.8)$ & $56(72.7)$ \\
\hline & Fair & 59 (76.6) & $50(64.9)$ & $33(42.9)$ & 49 (63.6) & $17(22.1)$ & $16(20.8)$ \\
\hline & Adequate & $14(18.2)$ & $9(11.7)$ & $10(13.0)$ & $14(18.2)$ & $7(9.1)$ & $5(6.5)$ \\
\hline \multirow[t]{3}{*}{ Nurses $(n=172)$} & None & $10(5.8)$ & $25(15.1)$ & $72(41.9)$ & $33(19.2)$ & $111(64.5)$ & $107(62.2)$ \\
\hline & Fair & 87 (50.6) & $113(65.7)$ & $84(48.8)$ & $93(54.1)$ & $50(29.1)$ & $56(32.6)$ \\
\hline & Adequate & $75(43.6)$ & $33(19.2)$ & $16(9.3)$ & $46(26.7)$ & $11(6.4)$ & $9(5.2)$ \\
\hline \multirow[t]{3}{*}{ Pharmacists $(n=30)$} & None & $0(0.0)$ & $9(30.0)$ & $7(23.3)$ & $5(16.7)$ & $22(73.3)$ & $20(66.7)$ \\
\hline & Fair & $16(53.3)$ & $19(63.3)$ & $21(70.0)$ & $22(73.3)$ & $8(26.7)$ & $10(33.3)$ \\
\hline & Adequate & $14(46.7)$ & $2(6.7)$ & $2(6.7)$ & $3(10.0)$ & $0(0.0)$ & $0(0.0)$ \\
\hline \multirow[t]{3}{*}{ Others $(n=83)$} & None & $3(3.6)$ & $18(21.7)$ & $35(42.2)$ & $19(22.9)$ & $55(66.3)$ & $58(69.9)$ \\
\hline & Fair & $58(69.9)$ & $51(61.4)$ & $41(49.4)$ & $46(55.4)$ & $21(25.3)$ & $20(24.1)$ \\
\hline & Adequate & $22(26.5)$ & $14(16.9)$ & $7(8.4)$ & $18(21.7)$ & $7(8.4)$ & $5(6.0)$ \\
\hline
\end{tabular}

CAM complementary and alternative medicine

Data are the number (percentage)

least (26\%). On the other hand, a greater proportion of pharmacists initiated discussion on CAM (46.7\%) and recommended CAM (50.0\%) (Fig. 2). A small percentage of nurses and pharmacists $(<10 \%)$ were more likely to refer patients to a CAM practitioner (Fig. 3). When confronted by CAM users regarding side effects or experiences about CAM, most HCPs $(>50 \%)$ remained neutral and did not offer an opinion on CAM use (Table 7).

Doctors (51.9\%), nurses (43.0\%), pharmacists (63.3\%), and other HCPs (43.4\%) said that combination therapy is superior to Conventional Medicine alone. HCPs believed that combination therapy increases patient satisfaction and assists in fighting illness (Table 8). The superiority of CAM, including greater satisfaction, ability to fight illness, and promotion of health and

Table 3 Results of chi-square tests of association with personal use of CAM and recommendation for the use of CAM

\begin{tabular}{|c|c|c|c|c|c|c|}
\hline \multirow[b]{2}{*}{ Variable } & \multicolumn{3}{|c|}{ Personal use of CAM } & \multicolumn{3}{|c|}{$\begin{array}{l}\text { Recommendation for the } \\
\text { use of CAM }\end{array}$} \\
\hline & $\overline{x^{2}}$ & $\mathrm{df}$ & $p$ & $x^{2}$ & $d f$ & $p$ \\
\hline Sex & 22.16 & 1 & $\leq 0.001$ & 23.81 & 1 & $\leq 0.001$ \\
\hline Ethnicity & 7.42 & 2 & 0.024 & 6.74 & 2 & 0.024 \\
\hline Religion & 15.16 & 4 & 0.004 & 4.619 & 4 & 0.329 \\
\hline Religiosity & 5.5 & 3 & 0.138 & 1.5 & 3 & 0.681 \\
\hline $\begin{array}{l}\text { Type of health } \\
\text { care provider }\end{array}$ & 19.07 & 3 & $\leq 0.001$ & 24.91 & 3 & $\leq 0.001$ \\
\hline Years of practice & 10.72 & 5 & 0.057 & 6.54 & 5 & 0.257 \\
\hline
\end{tabular}

CAM complementary and alternative medicine wellbeing, was supported mainly by pharmacists. HCPs, particularly doctors and nurses, feel the future lies in integrative medicine combining conventional medicine and evidence-based CAM (Table 9). Less than $10 \%$ of HCPs said conventional medicine should be used alone, and $12-26 \%$ said conventional medicine and CAM should be used at the discretion of the HCP.

\section{Discussion}

\section{Personal usage and prescribing practices}

In this study, the overall prevalence of CAM use among HCPs was high (82.3\%): nurses (92.4\%), pharmacists (83.3\%), other HCPs (82.3\%), and doctors (64.9\%). These are quite high rates considering HCP's training in evidence-based medicine. However, such prevalence rates are similar to those of other countries with folk

Table 4 Binary logistic regression analysis of personal use of CAM

\begin{tabular}{lllll}
\hline & & & \multicolumn{2}{l}{$95 \% \mathrm{Cl}$} \\
\cline { 4 - 5 } & OR & $p$ & Lower & Upper \\
\hline Years of practice & 0.927 & 0.414 & 0.772 & 1.113 \\
Sex & 2.452 & 0.010 & 1.245 & 4.830 \\
Ethnicity & 1.231 & 0.087 & 0.970 & 1.562 \\
Religion & 1.351 & 0.029 & 1.032 & 1.769 \\
Religiosity & 1.276 & 0.188 & 0.887 & 1.835 \\
Type of health & 0.854 & 0.015 & 0.753 & 0.970 \\
care provider & & & & \\
\hline CAM complementary & & & &
\end{tabular}

CAM complementary and alternative medicine, $\mathrm{Cl}$ confidence interval, $O R$ odds ratio 
Table 5 Binary logistic regression analysis of recommendation for the use of CAM

\begin{tabular}{lllll}
\hline & & & \multicolumn{3}{c}{$95 \% \mathrm{Cl}$} \\
\cline { 5 - 6 } & OR & $p$ & Lower & Upper \\
\hline Years of practice & 0.889 & 0.340 & 0.669 & 1.132 \\
Sex & 4.229 & 0.003 & 1.649 & 10.848 \\
Ethnicity & 0.988 & 0.936 & 0.744 & 1.314 \\
Religion & 1.259 & 0.216 & 0.874 & 1.813 \\
Religiosity & 1.004 & 0.988 & 0.616 & 1.636 \\
Type of health care provider & 0.854 & 0.023 & 0.746 & 0.978 \\
\hline
\end{tabular}

CAM complementary and alternative medicine, $C l$ confidence interval, $O R$ odds ratio

medicine tradition: $100 \%$ of pharmacy students in Sierra Leone [35] and 51\% of physicians at a paediatric hospital in Mexico [36]. In a previous study in Trinidad, $40.6 \%$ of physicians admitted to having used herbs [11]. Prevalences in developed countries are also quite high: 36 and 12\% among nurses and doctors, respectively, in Norway [37] and 40\% [29] and 76\% [38] among healthcare workers in two US studies. Predictors of CAM were found to be sex, religion, and HCP category. Spirituality and religiousness were found as predictors in other studies [39].

\section{CAM recommendation}

Despite the high HCP usage (Fig. 2), only 26\% of doctors recommended its usage. Wide variations exist between personal use of CAM and CAM recommendation. Similar to our study, Maha and Shaw found that most HCPs who use CAM personally, do not recommend it [40]. Clement et al. found that $40.6 \%$ of physicians have used herbs but only $27.1 \%$ recommended them to their patients [11]. HCPs, particularly doctors, may feel reluctant to prescribe CAM because of insufficient knowledge and evidence to justify CAM prescription, and ethical and legal obligations to patients. It may be difficult to justify the use of CAM (chelation therapy to dissolve plaques in CAD, boosters to improve strength and vitality, or herbs for cancer treatment) in the presence of well-tested conventional medicine, and when CAM is reported as unsafe and ineffective [41] by some physicians (18.5\%). This is in contrast to other studies that found that physicians who used CAM previously are more likely to recommend CAM to their patients $[42,43]$.

Doctors particularly felt that recommendations should be based on evidence-based guidelines, as in other studies [44, 45]. The perceived safety and its feature as a natural product by pharmacists made them more likely to prescribe CAM [46]. This may contribute to the $50 \%$ of pharmacists who recommended CAM in our study.

\section{Education and knowledge}

The majority of doctors (84.4\%), nurses (83.1\%), and pharmacists $(83.3 \%)$ felt that medical practitioners should be more educated on CAM. The desire to learn about CAM goes beyond curiosity and information but to acquire the knowledge to treat complications and drug interactions [27] and to communicate effectively with patients about CAM [47]. Physicians were generally more interested in learning about CAM therapies, while nurses regarded it as less important to have knowledge about CAM in comparison to other HCPs. Nonetheless, more than twice as many nurses (43.6\%) and pharmacists $(46.7 \%)$ as doctors $(<20 \%)$ reported to have adequate knowledge of herbal CAM.

\section{CAM communication}

Our study reveals that when confronted by CAM users on medical issues, the majority of doctors $(50.6 \%)$ and nurses $(52.6 \%)$ remain neutral or non-committal. This is despite the benefits and importance of communication between patients and doctors [48]. This may result from their inexperience or incompetence [30, 49] or lack of knowledge as was found in this study. Despite the multiple concerns, few doctors are prepared to listen to patients on CAM usage [48, 50]. Patients are, therefore, left unmonitored by professionals compromising safety and effectiveness of CAM therapies as in Trinidad.

Table 6 Correlation between reported knowledge of CAM and knowledge of specific CAM therapies/methods)

\begin{tabular}{lllllll}
\hline $\begin{array}{l}\text { Health care } \\
\text { provider }\end{array}$ & CAM method & & & & \\
\cline { 2 - 6 } & $\begin{array}{l}\text { Herbal } \\
r(p)\end{array}$ & $\begin{array}{l}\text { Spiritual } \\
r(p)\end{array}$ & $\begin{array}{l}\text { Alternative } \\
r(p)\end{array}$ & $\begin{array}{l}\text { Physical } \\
r(p)\end{array}$ & $\begin{array}{l}\text { Energy } \\
r(p)\end{array}$ & $\begin{array}{l}\text { Therapeutic } \\
r(p)\end{array}$ \\
\hline Doctors $(n=77)$ & $0.481(\leq 0.001)$ & $0.587(\leq 0.001)$ & $0.618(\leq 0.001)$ & $0.518(\leq 0.001)$ & $0.482(\leq 0.001)$ & $0.507(\leq 0.001)$ \\
Nurses $(n=172)$ & $0.199(\leq 0.001)$ & $0.181(0.291)$ & $0.244(\leq 0.001)$ & $0.180(0.018)$ & $0.215(0.008)$ & $0.195(0.010)$ \\
Pharmacists $(n=30)$ & $0.129(0.496)$ & $0.163(0.389)$ & $0.247(0.188)$ & $0.345(0.062)$ & $0.179(0.343)$ & $0.174(0.359)$ \\
Others $(n=83)$ & $0.424(\leq 0.001)$ & $0.385(\leq 0.001)$ & $0.359(0.001)$ & $0.392(\leq 0.001)$ & $0.431(\leq 0.001)$ & $0.451(\leq 0.001)$ \\
\hline
\end{tabular}




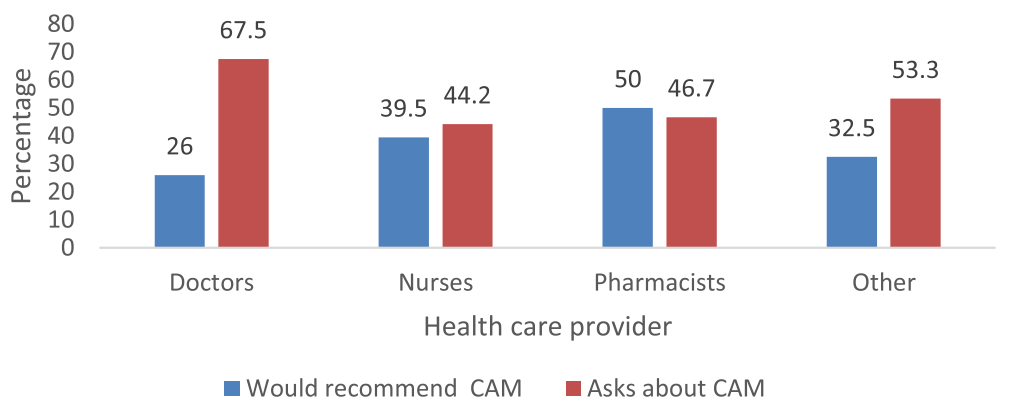

Fig. 2 Percentage of health care providers asking patients about CAM usage and who would recommend the use of CAM

\section{CAM usage}

At least $81.8 \%$ of doctors, $82.6 \%$ of nurses, and $83.3 \%$ of pharmacists felt that CAM should be tried and scientifically tested before usage. A substantial percentage of doctors (44.2\%) also felt it should be placed in a drug formulary. Most HCPs (doctors (61\%), nurses (42.4\%), pharmacists (53.3\%), and other HCPs (67.1\%)) believe that conventional medicine and evidenced based CAM should be integrated. Less than 35\% of HCPs felt that the combination of treatment should be at the doctors or patients' discretion while a small but significant percentage of doctors (10.4\%), nurses (3.5\%), pharmacists (6.7\%) and other HCPs (3.7\%) felt CM should be used alone.

\section{Future perspectives}

The patients' perceived benefits of CAM in holistic care [51-53], longevity [54], quality of life [10], as well assisting in the counteracting or destroying side effects of CM [22, 55] have encouraged its usage. Though Marusic's statement, "there is no sound proof of CAM effectiveness, no hypotheses on the mechanisms of their action, nor scientific reports testing them" [56] is contentious, there is a lack of evidence for most CAM. Our study revealed that healthcare providers prefer evidence based guidelines (EBG) of CAM for its recommendation. Controlled studies to determine outcomes such as health-related quality of life and additional outcomes related to whole-person health-physical, mental, social, and spiritual should be encouraged and emphasised [57]. Doctors are also concerned about "safety, lack of proof that therapies work, inadequate knowledge and experience with CAM among doctors and absence of statutory regulation for most therapies" $[58,59]$, thus making efforts to ensure safety, efficacy, and quality; access; and rational CAM use [60]. Participants of the study believe that the future of therapeutics lies in integrative medicine (Conventional Medicine and evidence-based CAM) as was also pointed out by Dobos [61].

This study has some limitations. First, the sample was not randomized; however, the questionnaires were distributed widely to nurses, doctors, and pharmacists across different departments and locations. Second,

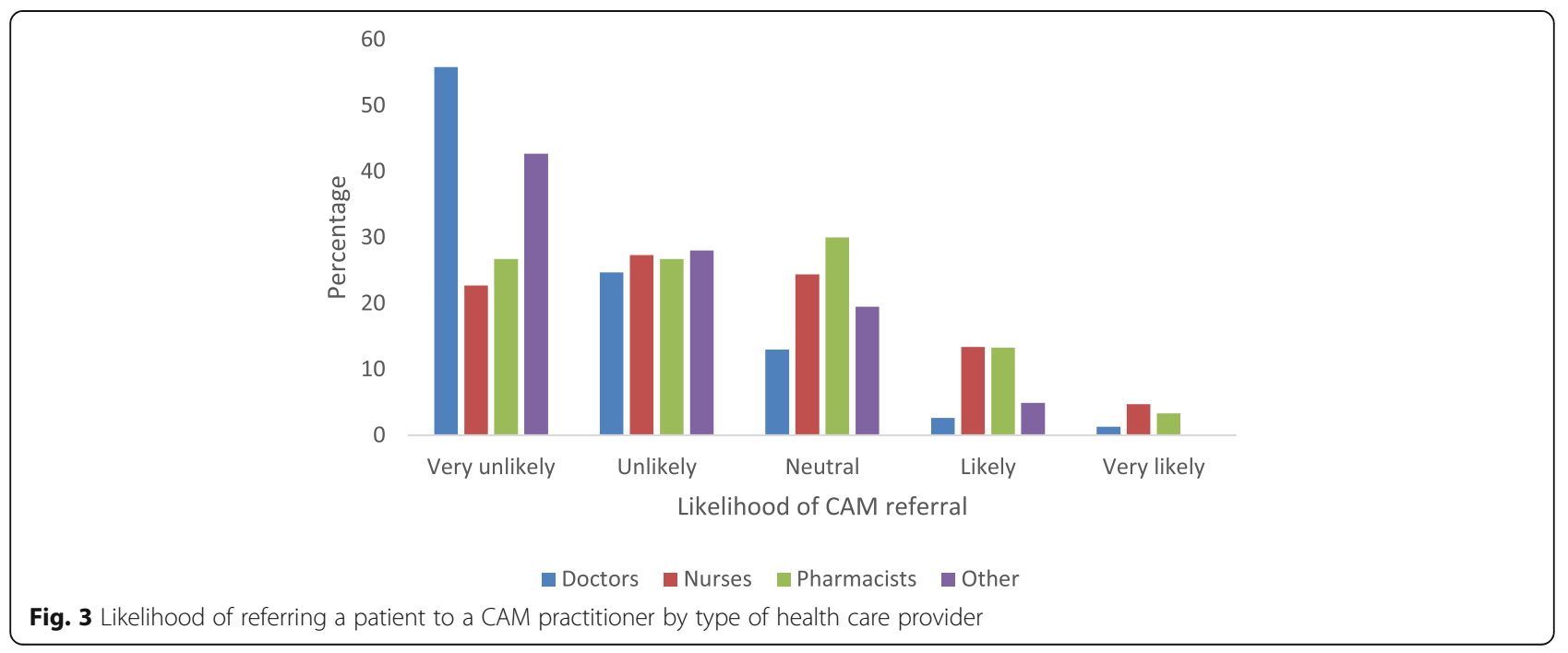


Table 7 Attitudes of health care providers towards CAM users: $n$ (\%)

\begin{tabular}{|c|c|c|c|c|c|c|}
\hline & Ignored patient & Recommended CAM & Remained neutral & Prescribed CAM and CM & Other & No response \\
\hline Doctors $(n=77)$ & $1(1.3)$ & $15(19.5)$ & $39(50.6)$ & $8(10.4)$ & $9(11.7)$ & $5(6.5)$ \\
\hline Nurses $(n=172)$ & $3(1.5)$ & $8(8.2)$ & $90(52.6)$ & $22(12.9)$ & $18(10.5)$ & $24(14.0)$ \\
\hline Pharmacists $(n=30)$ & $0(0.0)$ & $2(6.7)$ & $11(36.7)$ & $9(30.0)$ & $5(16.7)$ & $3(10.0)$ \\
\hline Others $(n=83)$ & $3(3.6)$ & $12(14.5)$ & $40(48.2)$ & $9(10.8)$ & $13(15.7)$ & $6(7.2)$ \\
\hline
\end{tabular}

CAM complementary and alternative medicine, $C M$ conventional medicine

Data are the number (percentage)

the sample was too small for subgroup analysis. Third, answers depended on memory recall, which may introduce bias. The sample, though comprising a group of experts, is influenced both from their heritage of centuries of traditional medicine from fore parents from Africa and India as well as modern day exposure to Chinese, Ayurvedic, and western (USA) and South American medicine. While the findings

Table 8 Attitudes towards CAM: $n(\%)$

\begin{tabular}{|c|c|c|c|c|}
\hline & $\begin{array}{l}\text { Doctors } \\
(n=77)\end{array}$ & $\begin{array}{l}\text { Nurses } \\
(n=172)\end{array}$ & $\begin{array}{l}\text { Pharmacists } \\
(n=30)\end{array}$ & $\begin{array}{l}\text { Others } \\
(n=83)\end{array}$ \\
\hline $\begin{array}{l}\text { Practicing with } \\
\text { knowledge of CAM and } \\
\text { CM is superior to } \\
\text { practicing with only } \\
\text { knowledge of CM }\end{array}$ & 40 (51.9) & $74(30.0)$ & 19 (63.3) & $36(43.4)$ \\
\hline $\begin{array}{l}\text { Incorporation of CAM } \\
\text { therapies can result in } \\
\text { increased patient } \\
\text { satisfaction }\end{array}$ & $43(55.8)$ & $100(58.1)$ & $21(70.0)$ & $53(63.9)$ \\
\hline $\begin{array}{l}\text { CAM therapies can assist } \\
\text { in fighting illness }\end{array}$ & $40(51.9)$ & $103(59.9)$ & $19(63.3)$ & $49(59.0)$ \\
\hline $\begin{array}{l}\text { CAM therapies can } \\
\text { promote general health } \\
\text { and wellness }\end{array}$ & $48(62.3)$ & $110(64.0)$ & $21(70.0)$ & $53(63.9)$ \\
\hline $\begin{array}{l}\text { Medical practitioners } \\
\text { should be more educated } \\
\text { in the use of CAM }\end{array}$ & $65(84.4)$ & $43(83.1)$ & 25 (83.3) & $63(75.9)$ \\
\hline $\begin{array}{l}\text { Would support } \\
\text { incorporation of CAM in } \\
\text { the medical curriculum }\end{array}$ & $53(68.8)$ & $126(73.3$ & $23(76.7)$ & $55(63.3)$ \\
\hline $\begin{array}{l}\text { Incorporation of CAM } \\
\text { therapies into the into the } \\
\text { health care system would } \\
\text { enhance patient care }\end{array}$ & 46 (59.1) & $126(73.3)$ & $18(60.0)$ & $52(62.7)$ \\
\hline $\begin{array}{l}\text { Would support CAM } \\
\text { being introduced in a } \\
\text { drug formulary }\end{array}$ & $34(44.2)$ & $117(60.8)$ & $16(53.3)$ & $38(45.8)$ \\
\hline $\begin{array}{l}\text { Research on the efficacy } \\
\text { and safety of CAM should } \\
\text { be performed }\end{array}$ & $63(81.8)$ & 142 (82.6) & $25(83.3)$ & $66(75.9)$ \\
\hline $\begin{array}{l}\text { Provision of wellness } \\
\text { centres using CAM and } \\
\text { CM would benefit } \\
\text { patients }\end{array}$ & $48(62.3)$ & $132(76.7)$ & $22(73.3)$ & $61(74.4)$ \\
\hline
\end{tabular}

CAM complementary and alternative medicine, CM conventional medicine Data are the number (percentage) may be unique to Trinidad, patients' characteristics and CAM practices are similar to other countries and these findings can be generalised to other HCPs in other countries.

\section{Conclusions}

The prevalence of CAM use among HCPs in Trinidad and Tobago was high (82.3\%). CAM use was more prevalent among nurses, followed by pharmacists, doctors, and other HCPs. However, knowledge about CAM was low, particularly among doctors, and the majority was reluctant to recommend CAM and to refer patients to a CAM practitioner. Sex, ethnicity, and type of $\mathrm{HCP}$ were associated with both personal use and recommendation for the use of CAM. Predictors of CAM use were sex, religion, and profession; predictors of recommendation for the use of CAM were sex and profession. Pharmacists, followed by doctors, other HCPs, and nurses, feel combination therapy is superior to $\mathrm{CM}$ alone. HCPs, particularly doctors and nurses, feel the future lies in integrative medicine combining Conventional Medicine and evidence-based CAM. Only a small percentage of HCPs feel CM should be used alone. There was inadequate communication with $\mathrm{HCPs}$, leaving patients largely unsupervised and unmonitored by medical personnel.

Table 9 How respondents see the future of CAM in medical practice: $n(\%)$

\begin{tabular}{lllll}
\hline & $\begin{array}{l}\text { Doctors } \\
(n=77)\end{array}$ & $\begin{array}{l}\text { Nurses } \\
(n=172)\end{array}$ & $\begin{array}{l}\text { Pharmacists } \\
(n=30)\end{array}$ & $\begin{array}{l}\text { Others } \\
(n=83)\end{array}$ \\
\hline CM alone & $8(10.4)$ & $6(3.5)$ & $2(6.7)$ & $3(3.6)$ \\
$\begin{array}{l}\text { CM and CAM at the } \\
\text { patient's discretion }\end{array}$ & $9(11.7)$ & $40(23.3)$ & $2(6.7)$ & $7(8.4)$ \\
$\begin{array}{l}\text { CM and CAM at the } \\
\text { doctor's discretion }\end{array}$ & $11(14.3)$ & $31(18.0)$ & $8(26.7)$ & $10(12.0)$ \\
$\begin{array}{l}\text { CM and evidence-based } \\
\text { CAM as integrative } \\
\text { medicine }\end{array}$ & $47(61.0)$ & $73(42.4)$ & $16(53.3)$ & $55(66.3)$ \\
No response & $2(2.6)$ & $22(12.8)$ & $2(6.7)$ & $7(8.4)$ \\
\hline
\end{tabular}

CAM complementary and alternative medicine, $C M$ conventional medicine Data are the number (percentage) 


\section{Abbreviations}

CAM: Complementary and alternative medicine; CM: Conventional medicine; HCP: Health care provider; NCCAM: National centre for complementary and alternative medicine; WHO: World Health Organization

\section{Acknowledgements}

We would like to thank Caroline Changoor (fourth year medical student) for her help with data collection. We would also like to thank all participants for giving their time to complete the questionnaire.

\section{Funding}

Not applicable.

\section{Availability of data and materials}

The data that support the findings of this study are available from the corresponding authors on request.

\section{Authors' contributions}

MB designed the study, collected the data or supervised data collection, and wrote the manuscript. GL assisted in the design of the study and performed the statistical analysis. All authors read and approved the final manuscript.

\section{Authors' information}

MB is a Specialist Medical Officer and Consultant Physician at San Fernando Hospital (San Fernando, Trinidad and Tobago) and a lecturer at the School of Medicine and Arthur Lok Jack Graduate School of Business at the University of the West Indies (Mt. Hope, Trinidad and Tobago). GL is a lecturer in statistics at the University of the West Indies (St. Augustine, Trinidad and Tobago).

\section{Competing interests}

The authors declare that they have no competing interests.

\section{Consent for publication}

Not applicable.

\section{Ethics approval and consent to participate}

This study received ethical approval from the Ethics Committee of SouthWest Regional Health Authority on $28^{\text {th }}$ September 2014. All participants gave their consent to participate in the study.

\section{Author details}

${ }^{1}$ School of Medicine and Arthur Lok Jack Graduate School of Business, University of the West Indies, St. Augustine, Trinidad and Tobago. ${ }^{2}$ University of the West Indies, St. Augustine, Trinidad and Tobago. ${ }^{3}$ House \#57 LP 62, Calcutta Road Number 3, McBean, Couva, Trinidad, Trinidad and Tobago.

\section{Received: 17 September 2016 Accepted: 28 February 2017}

\section{Published online: 08 March 2017}

References

1. National Center for Complementary and Alternative Medicine (NCCAM). Strategic object 3: increase understanding of 'real world' patterns and outcomes of CAM use and its integration into health care and health promotion. http://nccam.nih.gov/about/plans/2011/objective3.html. Accessed 26 Feb 2015

2. Harris PE, Cooper KL, Relton C, Thomas KJ. Prevalence of complementary and alternative medicine (CAM) use by the general population: a systematic review and update. Int J Clin Pract. 2012:66:924-39.

3. Barnes PM, Bloom B, Nahin R. Complementary and alternative medicine use among adults and children: United States, 2007. Natl Health Stat Report. 2008;12:1-23.

4. Posadzki P, Watson LK, Alotaibi A, Ernst E. Prevalence of use of complementary and alternative medicine (CAM) by patients/consumers in the UK: systematic review of surveys. Clin Med. 2013;13:126-31.

5. Xue CC, Zhang AL, Lin V, Da Costa C, Story DF. Complementary and alternative medicine use in Australia: a national population-based survey. J Altern Complement Med. 2007:13:643-50.

6. Ock SM, Choi JY, Cha YS, Lee J, Chun MS, Huh CH, et al. The use of complementary and alternative medicine in a general population in South Korea: results from a national survey in 2006. J Korean Med Sci. 2009;24:1-6.
7. Clement Y. Limited clinical evidence to support the integration of Caribbean herbs into conventional medicine. Focus Altern Complement Ther. 2011;16:289-92.

8. Moyne L, Stubbs R, Crowdy RE, Citrine W, Mackinnon P, Blacklock MG, et al. West India royal commission report. London: Her Majesty's Stationery Office; 1945 (Command 6607).

9. Bahall M. Complementary and alternative medicine usage among cardiac patients: a descriptive study. BMC Complement Altern Med. 2015:15:100.

10. Bahall M, Edwards M. Perceptions of complementary and alternative medicine among cardiac patients in South Trinidad: a qualitative study. BMC Complement Altern Med. 2015;15:99.

11. Clement YN, Williams AF, Khan K, Bernard T, Bhola S, Fortuné M, et al. A gap between acceptance and knowledge of herbal remedies by physicians: the need for educational intervention. BMC Complement Altern Med. 2005;5:20.

12. Clement YN, Baksh-Comeau YS, Seaforth CE. An ethnobotanical survey of medicinal plants in Trinidad. J Ethnobiol Ethnomed. 2015;11:67. doi:10.1186/ s13002-015-0052-0.

13. Mahabir D, Gulliford MC. Use of medicinal plants for diabetes in Trinidad and Tobago. Pan Am J Public Health. 1997:1:174-9.

14. Fraser M. Getting massage therapy. Trinidad Express Newspapers. 2014. http://www.trinidadexpress.com/featured-news/Getting-massage-therapy265979541.html. Accessed 16 Jan 2017

15. Age old techniques for present day ailments. Trinidad Express Newspaper. 2012. http://www.trinidadexpress.com/featured-news/Age_old_techniques_for_ present_day_ailments-138303564.html. Accessed 16 Jan 2017.

16. Ramcharitar R. News from the homeopathic front. The Trinidad Guardian Newspaper. 2015. http://www.guardian.co.tt/lifestyle/2015-07-01/newshomeopathic-front. Accessed 16 Jan 2017.

17. Eisenberg DM, Davis RB, Ettner SL, Appel S, Wilkey S, Rompay MV, et al. Trends in alternative medicine use in the United States, 1990-1997: results of a follow-up national survey. JAMA. 1998;280:1569-75.

18. Pattoo CK. Indigenous-Ayurvedic medicine in rural and urban areas of Trinidad and Tobago. 2012

19. Ramsawack AN. Lyn Goddard: With hands for healing. The Trinidad Guardian Newspaper. 2011. http://www.guardian.co.tt/lifestyle/2011/04/22/ lyn-goddard-hands-healing. Accessed 16 Jan 2017.

20. Clyne KS. Easing pain with Acupuncture. The Trinidad Guardian Newspaper. 2012. http://www.guardian.co.tt/lifestyle/2012-08-05/easing-pain-acupuncture. Accessed 17 Jan 2017.

21. Arthur K, Belliard JC, Hardin SB, Knecht K, Chen C, Montgomery S. Reasons to use and disclose use of complementary medicine use - an insight from cancer patients. Cancer Clin Oncol. 2013;2:81-92.

22. Ernst E. Patient education: complementary and alternative medicine treatments (CAM) for cancer (Beyond the Basics). In: UpToDate ${ }^{\circledast}$. 2015. http:// www.uptodate.com/contents/complementary-and-alternative-medicinetreatments-cam-for-cancer-beyond-the-basics. Accessed 6 July 2015

23. Jonas WB. Advising patients on the use of complementary and alternative medicine. Appl Psychophysiol Biofeedback. 2001;26:205-14

24. Mountifield R, Andrews JM, Mikocka-Walus A, Bampton P. Doctor communication quality and friends' attitudes influence complementary medicine use in inflammatory bowel disease. World J Gastroenterol. 2015;21:3663-70.

25. Upchurch DM, Rainisch BW. The importance of wellness among users of complementary and alternative medicine: findings from the 2007 national health interview survey. BMC Complement Altern Med. 2015:15:362.

26. Wapf $\mathrm{V}$, Busato A. Patients' motives for choosing a physician: comparison between conventional and complementary medicine in Swiss primary care. BMC Complement Altern Med. 2007;7:41.

27. Jones $\mathrm{V}$. Risks associated with complementary and alternative medicine (CAM): A brief overview. Science-Based Medicine. 2009. https:// sciencebasedmedicine.org/risks-associated-with-complementary-andalternative-cam-medicine-a-brief-overview/. Accessed 9 Jan 2017.

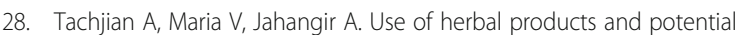
interactions in patients with cardiovascular diseases. J Am Coll Cardiol. 2010; 55:515-25.

29. Ventola CL. Current issues regarding complementary and alternative medicine (CAM) in the United States: part 1: the widespread use of CAM and the need for better-informed health care professionals to provide patient counseling. P T. 2010;35:461-8.

30. Bjerså K, Stener Victorin E, Fagevik Olsén M. Knowledge about complementary, alternative and integrative medicine (CAM) among 
registered health care providers in Swedish surgical care: a national survey among university hospitals. BMC Complement Altern Med. 2012;12:42.

31. Arcury TA, Bell RA, Altizer KP, Grzywacz JG, Sandberg JC, Quandt SA. Attitudes of older adults regarding disclosure of complementary therapy use to conventional physicians. J Appl Gerontol. 2013;32:627-45.

32. Jacobson GM, Cain JM. Ethical issues related to patient use of complementary and alternative medicine. J Oncol Pract. 2009;5:124-6.

33. Lwanga SK, Lemeshow S. Sample size determination in health studies: A practical manual. Geneva: World Health Organization; 1991. http://apps.who.int/iris/ bitstream/10665/40062/1/9241544058_(p1-p22).pdf. Accessed 9 Jan 2017.

34. Krejice RV, Morgan DW. Determining sample size for research activities. Educ Psychol Meas. 1970;30:607-10.

35. James PB, Bah AJ. Awareness, use, attitude and perceived need for complementary and alternative medicine (CAM) education among undergraduate pharmacy student in Sierra Leone: a descriptive crosssectional survey. BMC Complement Altern Med. 2014;14:438.

36. Martinez RG, Rodriguez CC, Carrillo MU, Solis MGO, Gonzalez MA, Colunga JCV, et al. Attitudes and uses of alternative medicine by physicians at a pediatric hospital in Mexico. Adv Appl Sociol. 2016;6:225-33.

37. Risberg T, Kolstad A, Johansen A, Vingerhagen K. Opinions on and use of alternative medicine among physicians, nurses and clerks in northern Norway. In Vivo. 1999;13:493-8.

38. Johnson PJ, Ward A, Knutson L, Sendelbach S. Personal use of complementary and alternative medicine (CAM) by U.S. health care workers. Health Serv Res. 2012;47(1):211-27.

39. Ellison CG, Bradshaw M, Roberts CA. Spiritual and religious identities predict the use of complementary and alternative medicine among US adults. Prev Med. 2012;54:9-12

40. Maha N, Shaw A. Academic doctors' views of complementary and alternative medicine (CAM) and its role within the NHS: an exploratory qualitative study. BMC Complement Altern Med. 2007;30:17.

41. Fakeye TO, Onyemadu O. Evaluation of knowledge base of hospital pharmacists and physicians on herbal medicines in Southwestern Nigeria. Pharm Pract (Granada). 2008:6:88-92.

42. Corbin Winslow L, Shapiro H. Physicians want education about complementary and alternative medicine to enhance communication with their patients. Arch Intern Med. 2002;162:1176-81.

43. Roy V, Gupta M, Ghosh RK. Perception, attitude and usage of complementary and alternative medicine among doctors and patients in a tertiary care hospital in India. Indian J Pharmacol. 2015;47:137-42.

44. Marwick C. Complementary medicine must prove its worth. BMJ. 2005;330:166.

45. Wahner-Roedler DL, Vincent A, Elkin PL, Loehrer LL, Cha SS, Bauer BA. Physicians' attitudes toward complementary and alternative medicine and their knowledge of specific therapies: a survey at an academic medical center. Evid Based Complement Alternat Med. 2006:3:495-501.

46. Kheir N, Gad HY, Abu-Yousef SE. Pharmacists' knowledge and attitudes about natural health products: a mixed-methods study. Drug Healthc Patient Saf. 2014;6:7-14.

47. Sudhinaraset $M$, Ingram $M$, Lofthouse HK, Montagu D. What is the role of informal healthcare providers in developing countries? a systematic review. PLoS One. 2013:8:e54978.

48. Cui Y. Open communication between patients and doctors about Complimentary and alternative medicine use: the key to avoiding harmful herb-drug interactions among cancer patients. Altern Integ Med. 2013;2:1.

49. Sewitch MJ, Cepoiu M, Rigillo N, Sproule D. A Literature review of health care professional attitudes toward complementary and alternative medicine. Complement Health Pract Rev. 2008;13:139.

50. Kemper KJ, Gardiner P, Gobble J, Woods C. Expertise about herbs and dietary supplements among diverse health professionals. BMC Complement Altern Med. 2006;6:15.

51. Astin JA. Why patients use alternative medicine: results of a national study. JAMA. 1998:279:1548-53.

52. Astin JA, Marie A, Pelletier KR, Hansen E, Haskell WL. A review of the incorporation of complementary and alternative medicine by mainstream physicians. Arch Intern Med. 1998;158:2303-10

53. O'Beirne M, Verhoef M, Paluck E, Herbert C. Complementary therapy use by cancer patients. Physicians' perceptions, attitudes, and ideas. Can Fam Physician. 2004;50:882-8.

54. Kooreman P, Baars EW. Patients whose GP knows complementary medicine tend to have lower costs and live longer. Eur J Health Econ. 2012;13:769-76.
55. Kemper KJ, O'Connor KG. Pediatricians' recommendations for complementary and alternative medical (CAM) therapies. Ambul Pediatr. 2004;4:482-7

56. Marusic M. "Complementary and alternative" medicine-a measure of crisis in academic medicine. Croat Med J. 2004;45:684-8.

57. Greeson JM, Rosenzweig S, Halbert SC, Cantor IS, Keener MT, Brainard GC. Integrative medicine research at an academic medical center: patient characteristics and health-related quality-of-life outcomes. J Altern Complement Med. 2008;14:763-7.

58. Botting A, Cook R. Complementary medicine: knowledge, use and attitudes of doctors. Complement Ther Med. 2000;6:41-7.

59. Fujiwara K, Imanishi J, Watanabe S, Ozasa K, Sakurada K. Changes in attitudes of Japanese doctors toward complementary and alternative medicine-comparison of surveys in 1999 and 2005 in Kyoto. Evid Based Complement Alternat Med. 2011:2011:608921.

60. World Health Organization Geneva. WHO Traditional Medicine Strategy 2002-2005. In: World Health Organization Western Pacific Region. 2002. http://www.wpro.who.int/health_technology/book_who_traditional_ medicine_strategy_2002_2005.pdf. Accessed 8 Aug 2016.

61. Dobos G. Integrative medicine - medicine of the future or 'old wine in new skins'? Eur J Integr Med. 2009;1:109-15.

\section{Submit your next manuscript to BioMed Central and we will help you at every step:}

- We accept pre-submission inquiries

- Our selector tool helps you to find the most relevant journal

- We provide round the clock customer support

- Convenient online submission

- Thorough peer review

- Inclusion in PubMed and all major indexing services

- Maximum visibility for your research

Submit your manuscript at www.biomedcentral.com/submit 